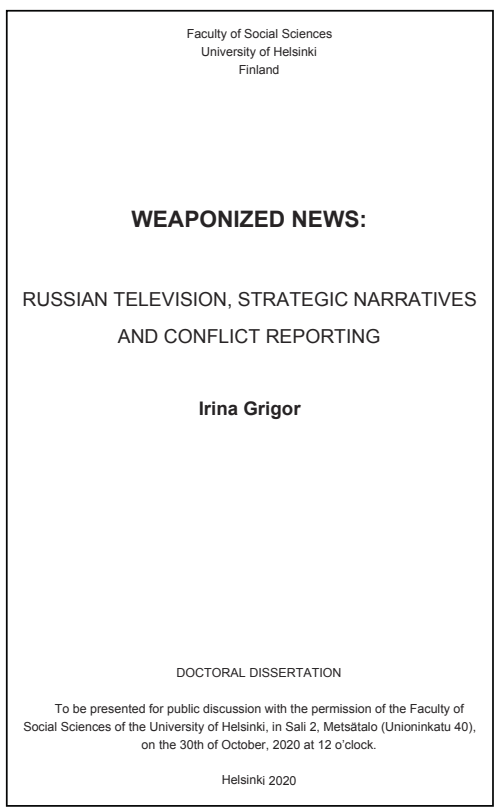

\title{
Weaponized News: Russian Television, Strategic Narratives and Conflict Reporting
}

\author{
Irina Grigor \\ Helsinki: Unigrafia 2020 \\ 100 sider, eks. enkeltstående artikler og appen- \\ dikser. ISBN 9789515166364
}

Omtalt av Karen-Anna Eggen [doktorgradsstipendiat, Institutt for forsvarsstudier, Forsvarets høgskole, kaeggen@mil.no]

Da president Vladimir Putin kom til makten i Russland ved årtusenskiftet var en viktig del av hans statsbyggingsprosjekt å skaffe seg kontroll over medielandskapet hjemme. Evnen til å forme egne innbyggeres oppfatning av virkeligheten har stått sentralt siden, og utover 2010-tallet har dette også inkludert et internasjonalt publikum. I sin doktorgradsavhandling i kommunikasjon fra Universitetet i Helsinki, gir Irina Grigor oss et nærmere innblikk i russisk bruk av media og strategiske narrativer, med særlig fokus på bruk av visuelle virkemidler i russiske medier i ulike caser i perioden 2012-2016.

Gjennom fire enkeltstående artikler får leseren et sammensatt bilde av hvordan russiske strategiske narrativer fremmes overfor ulike grupper og i ulike konflikter med det mål for øye å øke oppslutningen rundt myndighetenes beslutninger. Det russiske regimet bruker media til å samle støtte i egen befolkning, sympati ute i verden og forsvare ressursbruk i ulike kriger og konflikter. Dette er tematikk som har vært gjenstand for mye diskusjon, særlig etter Russlands annektering av Krim og påfølgende intervensjoner i Øst-Ukraina og i Syria, og som med alle kontroversielle saker, er det viktig at det gjøres grundig forskning på området. Grigor kobler sammen og analyserer bruken av tekst, lyd og bilde over tid, noe som gir henne et godt grunnlag for å diskutere og sammenligne komplekse nyanser i russiske mediers fremstilling av hendelser med stor nasjonal betydning. 
For at et strategisk narrativ skal være effektivt, må det finne gjenklang i verdier, forventninger og fordommer som gjør seg gjeldende hos målgruppen en søker å påvirke i et gitt historisk tidsrom (s. 63). Ifølge Grigor er det særlig tre hovednarrativ som Russland benytter for å oppnå strategisk effekt. Det første setter søkelys på Russlands forhold til Vesten, da særlig det Russland betrakter som USAs hegemoni, Vestens dårlige behandling av Russland og anti-russiske holdninger i USA og Europa. Dette narrativet brukes først og fremst i mediereportasjer som henvender seg til et utenlandsk publikum. Det andre hovednarrativet bygger på krigshistorie og Russlands kamp mot - og seier over - fascismen og nazismen under andre verdenskrig. Denne fortellingen retter seg særlig mot et hjemlig publikum og ble hyppig brukt i opptrappingen og underveis i konflikten med Ukraina. Det tredje hovednarrativet bygger på fortellingen om Russland som en leder blant slaviske nasjoner. I et russisk perspektiv er de slaviske land tett forbundet historisk, kulturelt og religiøst. Metaforen som brukes er at de er brødre. Russland spiller rollen som storebror, Ukraina er i dette tilfelle den avhengige lillebroren. Alle narrativene har historiske referanser som aktivt brukes for å intensivere ønskede budskap via media i kriser og konflikt.

Forfatteren gjør et interessant grep når hun deler opp avhandlingen sin i tre perspektiver; et komparativt, et retrospektivt og et hybrid mediaperspektiv. Førstnevnte gir innblikk i forskjeller i dekningen av ulike konflikter, her representert ved Ukraina og Syria, samt nyheter vinklet mot et hjemlig og internasjonalt publikum. I det andre perspektivet undersøkes narrativene over tid for å spore endringer. Det siste perspektivet - det forfatteren kaller et hybrid mediaperspektiv - gjør det mulig å se nærmere på samspillet mellom tradisjonelle og sosiale medier, og spredningen av falske nyheter.

Særlig sistnevnte perspektiv er verdt å vie noen ekstra linjer. Mens russiske myndigheter kontrollerer tradisjonelle medieplattformer hjemme, representerer internett et rom hvor Kremls narrativer utfordres. Ifølge Grigor resulterer dette i et behov for å opprettholde en konstant strøm av nye, engasjerende historier som skaper debatt om saker russiske myndigheter ønsker skal få oppmerksomhet. Dette inkluderer bruken av falske nyheter og et virvar av sensasjonelle, halvsanne og andre typer reportasjer for å forvirre og distrahere lesere (s. 62). Strategiske narrativer kan selvsagt søke å bidra med rasjonelle og faktabaserte fremstillinger. Poenget er at de også, særlig i de russiske tilfellene Grigor undersøker, spiller på følelser og søker å viske ut grensene mellom hva som er sant og usant.

Strategiske narrativer er ikke statiske enheter. De endres basert på målgruppen de henvender seg til, hvilke konflikter de dekker, hvordan disse utvikler seg over tid, samt hvordan massemedia reflekterer og bidrar til endringer i forholdet mellom to eller flere land (s. 65). For eksempel fokuserte dekningen av Ukraina-konflikten på sivile lidelser på pro-russisk side, mens reportasjene fra Syria sørget for å fremheve russisk militær dominans. Selv om Grigor i liten grad diskuterer viktigheten av symbolisme i russisk politikk, får hun belyst interessante nyanser i bruk av bilder 
og video i russiske medier - og rollen disse spiller. Hun finner at det er høy grad av samsvar mellom bruk av visuelle virkemidler og strategiske narrativer, men at de visuelle virkemidlene ikke nødvendigvis reflekterer det tekstuelle innholdet i reportasjen. Et godt eksempel er russiske reportasjer om påstått tortur av sivilbefolkningen i Øst-Ukraina utført av ukrainske styrker, hvor budskapet understøttes av patriotisk musikk og videomontasjer som viser lidende sivile under andre verdenskrig.

Grigor plasserer begrepet «strategiske narrativer» innenfor den større kategorien mange vestlige forfattere og kommentatorer kaller «informasjonskrigføring» (information warfare) (s. 18). Det har i nyere tid blitt mer vanlig i forskningslitteraturen om russisk strategi å snakke om dette som «informasjonskonfrontasjon» (informatsionnoje protivoborstvo), et begrep som bedre speiler helheten i russisk informasjonsstrategi og det begrepet russiske myndigheter og militærpersonell selv bruker. I russisk terminologi brukes som oftest «informasjonskrigføring» kun om vestlige/amerikanske fremgangsmåter. Grigor kunne også med fordel ha redegjort grundigere for hvordan hun har kommet frem til de ulike hovednarrativene og hovedperspektivene hun legger til grunn for sin analyse.

Avhandlingen er spennende lesning, og den gir et godt innblikk i russiske strategiske narrativer, deres innhold og bruksområder. Selv om Grigor ikke setter søkelys på aktørene som sådan, er det viktig at antakelser om russiske myndigheters mediebruk, som mange tar som en selvfølge, får en solid empirisk grunn å stå på. I et medielandskap hvor felles virkelighetsforståelser står svakere og det i større grad spilles på folks følelser, trengs grundig forskning på bruken av staters og medienes virkemidler - og Grigors avhandling er i så måte et godt bidrag. 